ks. Kazimierz Dullak

Ius Matrimoniale

$31(2020) \mathrm{nr} 2$

DOI:10.21697/im.2020.31.2.02

Wydział Teologiczny Uniwersytetu Szczecińskiego

ORCID 0000-0002-9202-0433

\title{
Przygotowanie dalsze i bliższe do małżeństwa po Dekrecie ogólnym Konferencji Episkopatu Polski z 2019 r.
}

Treść: Wstęp. 1. Przygotowanie dalsze. 2. Przygotowanie bliższe. Wnioski

\section{Wstęp}

Do momentu wejścia w życie Dekretu ogólnego o przeprowadzeniu rozmów kanoniczno-duszpasterskich $z$ narzeczonymi przed zawarciem małżeństwa kanonicznego Konferencji Episkopatu Polski z 1.06.2020 r. ${ }^{1}$ podstawą do podejmowania działań przygotowawczych do zawarcia małżeństwa była Instrukcja Konferencji Episkopatu Polski o przygotowaniu do zawarcia małżeństwa w Kościele katolickim z 1986 r. $^{2}$ Ten ostatni dokument w sposób szeroki ujmował

1 Konferencja Episkopatu Polski, Dekret ogólny o przeprowadzeniu rozmów kanoniczno-duszpasterskich z narzeczonymi przed zawarciem małżeństwa kanonicznego, w: https://episkopat.pl/aktakep312019 (dostęp 15.01.2021). (Dalej: DO). Dekret został wydany 8.10.2019 r., następnie 4.11.2019 r. uzyskał recognitio Kongregacji ds. Biskupów, natomiast 26.11.2019 r. został promulgowany przez Przewodniczącego KEP, a wszedł w życie 1.06.2020 r.

2 Konferencja Episkopatu Polski, Instrukcja Konferencji Episkopatu Polski o przygotowaniu do zawarcia małżeństwa w Kościele katolickim, Akta Konferencji Episkopatu Polski 1 (1998), s. 85-137. Dokument został wydany 5.09.1986 r., następnie 17.01.1987 r. uzyskał recognitio Kongregacji ds. Biskupów, natomiast 13.12.1989 r. został promulgowany przez Przewodniczącego KEP i wszedł w życie. 
przedmiotową tematykę: dawał wskazania dotyczące dalszego i bliższego przygotowania do małżeństwa oraz precyzował bardziej szczegółowo bezpośrednie działania przygotowawcze. Przyjęło się, nie tylko w mowie potocznej, stwierdzenie ${ }^{3}$, że dekret ogólny KEP zastępuje wcześniej obowiązującą instrukcję. Taka konstatacja jest nie do końca precyzyjna. Nie wchodząc w szczegóły związane z nazwą obu dokumentów i znaczeniem prawnym, należy szczególnie zauważyć to, że pierwszy z dokumentów w kolejności chronologicznej jest szerszy co do zasięgu przedmiotowego, zaś drugi koncentruje się zasadniczo na rozmowie kancelaryjnej, zwanej egzaminem przedmałżeńskim. Celem spotkań kancelaryjnych jest wyeliminowanie wszelkich przeszkód i okoliczności przeciwnych do zawarcia małżeństwa ważnego i godziwego.

Mając na uwadze przygotowanie do małżeństwa należy zwrócić uwagę na konieczność współpracy w tym dziele zarówno rodziny, społeczeństwa, jak i Kościoła. Wspierając i umacniając chrześcijańskie małżeństwa, Kościół winien popierać „lepsze i intensywniejsze programy przygotowania do małżeństwa, ażeby wyeliminować, na ile to możliwe, trudności, z którymi boryka się tyle małżeństw, a bardziej jeszcze po to, aby stworzyć pozytywne warunki do powstania i dojrzewania udanych małżeństw"4.

Przygotowanie do małżeństwa winno być ukierunkowane na to, by przyszli małżonkowie zostali wychowani i ukształtowani w taki sposób, by mogli ziszczać treść celebracji małżeńskiej realizując

3 Na wskazaną zastępowalność dokumentów wskazał P. GrzywAczEwski, Informacje dotyczace nowego formularza protokołu z przeprowadzenia rozmowy kanoniczno-duszpasterskiej z narzeczonymi przed zawarciem małżeństwa kanonicznego, p. 3, w: https://duszpasterski.pl/komentarz-do-dekretu-kep-z-2019-r (dostęp 15.01.2021).

4 IoAnnes Paulus PP. II, Adhortatio apostolica ad Episcopos, Sacerdotes et Christifideles totius Ecclesiae Catholicae: de Familiae Christianae muneribus in mundo huius temporis Familiaris consortio, 22.11.1981, AAS 74 (1982), s. 81-191, n. 66. Tekst polski: JAn PAwEŁ II, Adhortacja apostolska Familiaris consortio, 22.11.1981, w: S. MaŁysiak (red.), Adhortacje Ojca Świętego Jana Pawła II, t. 1, Kraków 1996, s. 65-160. (Dalej: FC). 
w sposób odpowiedzialny misję, do której będą przeznaczeni. Dzięki procesowi wychowania i edukacji w pierwszorzędnych wartościach stanowiących o małżeństwie, nupturienci będą zdolni stanąć „przed ołtarzem” z poczuciem odpowiedzialności za misję związaną z podjętym powołaniem.

Celem niniejszego opracowania jest wskazanie obowiązujących regulacji prawnych i duszpasterskich w Polsce, stanowiących podstawę procesu formowania kandydatów do małżeństwa. Materiał bazowy stanowią dokumenty Konferencji Episkopatu Polski z uwzględnieniem tych aktów prawnych Kościoła powszechnego, na których polskie prawo jest osadzone.

\section{Przygotowanie dalsze}

Dyrektorium duszpasterstwa rodzin ${ }^{5}$ jest odpowiedzią episkopatu Polski na oczekiwania ze strony Stolicy Apostolskiej. ${ }^{6}$ Przygotowaniom do małżeństwa poświęcono drugi rozdział zawierający numery 18-36. Struktura została osadzona na schemacie rozpropagowanym przez Jana Pawła II: przygotowanie dalsze, bliższe i bezpośrednie ${ }^{7}$. W interesującej nas, na tym etapie, pierwszej części dokumentu episkopat podkreśla, iż chodzi o zdobycie odpowiedniej wiedzy i osiągnięcie odpowiednich cnót związanych z życiem rodzinnym. Ten podstawowy etap kształtowania młodego człowieka dokonuje się w rodzinie. W sposób szczególny należy wyeksponować rolę rodziców jako wychowawców przygotowujących do małżeństwa. Zadanie to jest częścią roli, do spełnienia której rodzina jest powołana w społeczeństwie i w Kościele. Stąd, w wypełnianiu tego zadania rodzina powinna postępować zawsze w łączności ze wspólnotą Kościoła. Ten etap

\footnotetext{
5 Konferencja Episkopatu Polski, Dyrektorium duszpasterstwa rodzin, 1.05.2003, Warszawa 2003, s. 23. (Dalej: DDR).

6 PApieska RAda Ds. Rodzin, Przygotowanie do sakramentu małżéstwa, 13.05.1996, n. 15. (Dalej: PSM), w: M. BRZEZIŃski (red.) W trosce o dobro małżénstwa i rodziny. Dokumenty Papieskiej Rady ds. Rodzin, Lublin 2010, s. 176 i nn.

7 FC, 66.
} 
charakteryzuje się mnogością wariantów wpływających na kształt i postęp rozwoju. Należy mieć tu na uwadze zarówno kondycję odpowiedzialnych za rodzinę, jak i ich potomstwo; różne formy oddziaływania na poszczególnych etapach życia dzieci: dzieciństwo, okres dorastania, młodość. Jednym ze wspólnych mianowników procesu wychowawczego jest przyczynianie się rodziny do kreowania klimatu przyjaźni, ułatwiającego zaufanie, w celu nabierania cech nadprzyrodzonych za sprawą pomocy Bożej pozyskiwanej przez modlitwę i sakramenty. Rodzice dając przykład swoją postawą jednocześnie podejmują wysiłek wychowawczy ${ }^{8}$. Zgodnie z nauczaniem papieskim, wysiłek ten polega na przekazywaniu wartości ogólnoludzkich i chrześcijańskich. „Rodzina winna tak przygotować dzieci do życia, aby każde wypełniło całkowicie swe zadanie, zgodnie $\mathrm{z}$ otrzymanym od Boga powołaniem" ". Następnie rolą rodziców wobec dzieci jest odpowiednie ukierunkowanie i doradzenie w kwestii wyboru własnej przyszłości, tak jednak, by ten wybór nie płynął z nacisków rodzicielskich ${ }^{10}$. Rzeczone przygotowanie osiąga swe cele wówczas, gdy stanowi ono proces stopniowy i ciągły, urzeczywistniając wychowanie, które prowadzi do życia w prawdzie ${ }^{11}$. W wychowaniu takim niezastąpioną rolę odgrywa „chrześcijański styl życia”, którego świadectwo dają rodziny chrześcijańskie. Kiedy dzieci postrzegają, że ich rodzice działają zawsze jednomyślnie, i że z radością i hojnością oddają siebie dla dobra rodziny, otrzymują najlepszą lekcję swego przyszłego życia małżeńskiego. Ponadto, wspólny udział w budowaniu dobra w otoczeniu mają wzajemny szacunek i miłość rodziców. Dokument episkopatu w bardzo skonkretyzowany sposób wskazuje

\footnotetext{
8 PSM, 23-24.

9 FC, 53.

10 KKK, 2230; Pontificium Consilium Pro Familia, Carta de familiae iura, 22.10.1983, w: Enchiridion Vaticanum, t. 9, s. 538-552. Tekst polski w: L'Osservatore Romano (wyd. pol.) 4 (1983), nr 10, s. 5-6, art. 1a.

11 Concilium Oecumenicum Vaticanum II, Declaratio de educatione christiana Gravissimum Educationis, 28.10.1965, AAS 58 (1966) s. 728-739; tekst polski: Deklaracja o wychowaniu chrześcijańskim, w: SoвóR WatyкаŃski II, Konstytucje. Dekrety. Deklaracje, Poznań 2002, n. 2, s. 316.
} 
na praktyki religijne integrujące członków rodziny, są to: codzienna wspólna modlitwa, coniedzielna wspólnie przeżywana Eucharystia w łączności z przyjmowaniem Komunii św. oraz regularne korzystanie z sakramentu pojednania i pokuty ${ }^{12}$. Jan Paweł II konkludując omawiany etap przygotowania jednoznacznie stwierdza, $i \dot{z}$ „przygotowanie dalsze zaczyna się już w dzieciństwie, w tej mądrej pedagogii rodzinnej, nastawionej na doprowadzenie dzieci do odkrycia siebie jako istot obdarzonych złożoną i bogatą psychiką oraz własną osobowością z jej mocnymi i słabymi stronami. Jest to okres, w którym powinno się zaszczepić szacunek dla każdej zdrowej wartości ludzkiej, tak w stosunkach międzyosobowych, jak i społecznych, z tym wszystkim co ma znaczenie dla kształtowania charakteru"13.

Z pomocą naprzeciw obowiązkom rodziców wychodzi szkoła i Kościół. Choć szkoła jest w ogromnej mierze nastawiona na przekaz wiedzy, to jednak nie może sama ani nikt inny zwolnić jej z funkcji wychowawczej. Aby nurt wiedzy i działania wychowawcze były skorelowane na dobro dzieci, wpływ na to mają rodzice. Oni ostatecznie decydują o tym, jakie metody wychowawcze zostaną w szkole zastosowane i ku jakim celom zmierzają. Rodziców „prawem i obowiązkiem jest interesować się i decydować, kto będzie uczył ich dzieci, czego je będzie uczył i do czego będzie je wychowywał"14. Pomocna rola duszpasterza może polegać, na tym etapie, na organizowaniu spotkań ze specjalistami w dziedzinie wychowania, by zaproponować rozwiązania adekwatne do konkretnych potrzeb. We wszystkich tych działaniach chodzi również o odsunięcie tego typu inicjatyw, które mogą mieć zdrożny wpływ na dzieci i młodzież, poprzez źle pojętą edukację seksualną ${ }^{15}$. Poza odpowiedzialną rolą wychowawczą duszpasterza jawi się również zadanie wynikające z posługi nauczyciela wiary. Aby katecheza na poszczególnych etapach była prawdziwą kuźnicą postaw wypływających z wiary, należy zatroszczyć się o odpowiedni

\footnotetext{
12 DDR, 20.

13 FC, 66.

14 DDR, 21

15 TAMŻE.
} 
dobór katechetów, dostosowanie trafnych metod przekazu i mieć na uwadze ciągłą troskę o adekwatność poruszanej problematyki $\mathrm{w}$ ramach lekcji religii ${ }^{16}$.

Tak jak szkoła i Kościół stoją u boku rodziny celem niesienia wsparcia podstawowej komórce społecznej w dziele wychowawczego trudu przyszłych pokoleń, episkopat Polski zwrócił uwagę na rolę grup rówieśniczych. Położenie akcentu na młodzież, która wzajemnie dla siebie stanowi autorytet, jest bardzo trafnym zabiegiem socjotechnicznym w procesie wychowawczym. Rolą dorosłych, począwszy od rodziców, przez nauczycieli i duszpasterzy, aż po samorządowców, jest podjęcie starań skierowanych ku stworzeniu warunków, by młodzież mogła poza lekcjami spotykać się na gruncie szkolnym, kościelnym czy środowiskowym. Wsparcie młodych w organizowaniu i otoczenie opieką takich grup jak harcerstwo, oaza, KSM czy koła różańcowe oraz wiele innych, może prowadzić do uczenia się odpowiedzialności i kształtowania wielu przymiotów, które w późniejszym etapie będą przydatne w odpowiedzialnym wchodzeniu w związki małżeńskie ${ }^{17}$.

\section{Przygotowanie bliższe}

Jan Paweł II w Familiaris consortio wskazując na przygotowanie bliższe, stwierdza iż stanowi ono bardziej specyficzne przygotowanie do małżeństwa, dlatego zachęca do ponownego jego odkrycia ${ }^{18}$. Dokonuje się to przez katechezy, dzięki którym katechizowani poznają, czym jest małżeństwo chrześcijańskie, a przez to, by w sposób jak najbardziej owocny sprawowali i przeżyli sakrament stojący u progu ich wspólnego życia. Wspomniana predyspozycja dotyczy zarówno dziedziny moralnej, jak i duchowej. Następnie katecheza ma prowadzić do przygotowania do życia we dwoje, tzn. ma ukazać małżeństwo jako relację personalną mężczyzny i kobiety, która jest dynamiczna i wymaga nieustannego rozwoju. Ponadto, ten etap przygotowania

\footnotetext{
16 PSM, 25; DDR, 22.

17 DDR, 23.

18 FC, 66.
} 
prowadzi do pogłębienia problematyki płciowości małżeńskiej i odpowiedzialnego rodzicielstwa. Wynikiem, już na tym etapie, jest to, że przygotowujący się do małżeństwa zapoznają się zarówno z właściwymi metodami wychowania dzieci, jak również z podstawowymi elementami potrzebnymi w uporządkowanym prowadzeniu rodziny, takimi jak: stała praca, zarządzanie budżetem domowym, mądre gospodarowanie ${ }^{19}$. Autor adhortacji zwrócił również uwagę na potrzebę przygotowania młodych do apostolstwa rodzinnego, czyli do braterstwa i współpracy z innymi rodzinami. Jednocześnie zachęca do włączenia się w stowarzyszenia, ruchy i inicjatywy mające na celu ludzkie i chrześcijańskie dobro rodziny ${ }^{20}$.

Treści nauczania Jana Pawła II stanowią bardzo znaczący, jak się z czasem okaże, punkt odniesienia do dalszego nauczania Kościoła. Warto choćby wskazać na taką instytucję jak Papieska Rada ds. Rodziny. To ona w dokumencie z maja 1996 r. przedstawiła propozycje przebiegu przygotowania bliższego do małżeństwa. Ten etap jest adresowany do narzeczonych, ma być sprawdzianem dojrzałości w budowaniu relacji przyjaźni i dialogu oraz pogłębianiu życia wiarą. „Jest to ważny etap ewangelizacji, w którym muszą przypatrzeć się sobie w świetle wiary - na płaszczyźnie osobistej i wspólnotowej"21. Temu celowi ma pomóc zarówno uczestnictwo w katechezie opartej na słowie Bożym ${ }^{22}$, jak również zapoznanie się przez młodych z podstawowymi elementami nauk społecznych, medycznych i prawnych w zakresie dotyczącym małżeństwa i rodziny ${ }^{23}$. Szczególny akcent kładzie się na relacje między mężczyzną a kobietą, podejmowane w sposób wolny w jedności i ukształtowane jako nierozerwalne, z poczuciem odpowiedzialności rodzicielskiej i wzajemnie za siebie. To

19 TAmżE; M. Braun-GaŁKowska, Wychowanie do małżenstwa i rodziny, w: T. Styczeń (red.), Jan Paweł II, Familiaris consortio. Tekst i komentarze, Lublin 1987, s. 181-191.

20 FC, 66.

21 PSM, 32.

22 PSM, 34.

23 A. Sarmiento, Małżeństwo chrześcijańskie. Podręcznik teologii małżeństwa i rodziny, Kraków 2002, s. 199-200. 
prowadzi do poznania i ukształtowania zasad moralnych i uformowania sumienia ${ }^{24}$. O ile pojawiłyby się na tym etapie deficyty dotyczące wystarczającej dojrzałości psychicznej czy emocjonalnej, wówczas zadaniem rodziców lub opiekunów jest, by wsparli narzeczonych w podjęciu pracy nad swoim charakterem i kształtowaniu odpowiednich postaw eliminujących ograniczenia mogące mieć ujemny wpływ na budowanie przyszłości w sposób odpowiedzialny ${ }^{25}$.

Omawiany dokument w kilku miejscach kładzie charakterystyczny nacisk na kształtowanie życia duchowego. Zachęca do korzystania z sakramentów, zwłaszcza pojednania i Eucharystii ${ }^{26}$, te bowiem sakramenty w znaczącej mierze wpływają na kształtowanie sumienia i konkretnych postaw moralnych ${ }^{27}$. Ponadto, w tym rozwoju bardzo zalecana jest lektura Pisma Świętego ${ }^{28}$, udział w katechezie, zaangażowanie w apostolat - świadectwo wobec otaczającego świata. Innym ważnym elementem formacyjnym jest codzienna modlitwa narzeczonych, gdyż ona uzdalnia do kreowania postaw wynikających z przynależności do Chrystusa. Ponadto wybrzmiewa zalecenie kierowane do narzeczonych o zachowanie czystości przedmałżeńskiej, a co za tym idzie - wykluczenie zamieszkania razem, współżycie przedmałżeńskie oraz inne zachowania jak małżeństwo na próbę ${ }^{29}$.

Przygotowanie bliższe do małżeństwa zakładające całościowy rozwój kandydatów nie pomija w formacji aspektu społecznego, chodzi o przygotowanie do zadań ukierunkowanych na uformowanie postawy obywatelskiej, odpowiedzialnej za Kościół, jak również za własną rodzinę, której dadzą początek ${ }^{30}$. Kandydaci do małżeństwa

\footnotetext{
24 PSM, 35.

25 PSM, 36; A. GRYGIEL, Narzeczeni w relacji do swoich rodziców. Jak rodzice moga pomóc swoim dzieciom w dobrym wykorzystaniu czasu narzeczeństwa?, w: G. WĄCHOL (red.), Człowiek w relacji do... Rozważania o człowieku jako istocie relacyjnej, Kraków 2020, s. 219.

26 PSM, 41.

27 PSM, 35, 40.

28 PSM, 34.

29 PSM, 37.

30 PSM, 38.
} 
uczą się takiej postawy jeszcze przed ślubem, wchodzą na drogę wzajemnej wierności, bycia darem dla siebie, a to wymaga od nich wyrzeczenia i uczenia się szacunku wzajemnie wobec siebie ${ }^{31}$.

Wskazana w dokumencie wieloaspektowość przygotowań kandydatów do małżeństwa wymaga zaangażowania grona osób nie tylko przygotowanych w wielu szczegółowych dziedzinach życia, ale również gotowych do poświęcenia czasu i chętnych do dzielenia się zasobami swojej wiedzy i doświadczenia. „Prowadzący przygotowanie do małżeństwa powinni otrzymać formację w specjalnych Instytutach Pastoralnych i być starannie dobrani przez Biskupa"32. Papieska Rada akcentuje potrzebę zaangażowania się w przygotowanie do małżeństwa zarówno duchownych - kształtujących postawy moralne i przekazujących wiedzę teologiczną, jak również specjalistów w medycynie, prawie czy psychologii. Zespół wsparcia na tym etapie przygotowania powinien składać się z osób „o pewnej doktrynie i bezdyskusyjnej wierności Magisterium Kościoła”33. Szczególnie mocno położono nacisk, w omawianym przygotowaniu, na przejawy wiary dotyczące sakramentu małżeństwa.

Znaczącym dopowiedzeniem w przedmiotowej dziedzinie jest wypowiedź Benedykta XVI skierowana do członków Trybunału Roty Rzymskiej w dniu 22 stycznia 2011 r. ${ }^{34}$ Papież zwrócił uwagę na sposób podejścia do przygotowania się do zawarcia małżeństwa przez narzeczonych, jak i duszpasterzy. Wskazał, że w programach kursów przedmałżeńskich nie przykłada się należytej wagi do zagadnień kanonicznych, uważając je za nieistotne. Jednocześnie funkcjonuje w społeczeństwie przekonanie o konieczności adekwatnego przygotowania, ale to nie przekłada się na pogłębione zaangażowanie narzeczonych. Dominuje tendencja, by duszpasterze wielkodusznie dopuszczali do zawarcia małżeństwa pary osób chcące zawrzeć

\footnotetext{
31 PSM, 39-40.

32 PSM, 44.

33 PSM, 43.

34 Benedictus XVI, Ad sodales Tribunalis Romanae Rotae, AAS 103 (2011), s. 108-113.
} 
małżeństwo, kierując się jedynie prawem naturalnym będącym podstawą dążenia do zawarcia związku. Papież podkreśla, że faktycznie ius connubii jest prawem do zawarcia prawdziwego małżeństwa, ale trzeba mieć na uwadze podstawową zasadę: omnes possunt matrimonium contrahere, qui iure non prohibentur ${ }^{35}$. Odpowiednie przygotowanie do małżeństwa stoi na straży właściwego podejścia do tej instytucji, do odpowiedzialnego podjęcia wszystkich niezbędnych obowiązków związanych z dobrem przyszłego związku. Według Benedykta XVI, przygotowanie do zawarcia małżeństwa jest ściśle zaplanowanym dążeniem do pełnego zjednoczenia w małżeństwie na wzór Chrystusa, który umiłował Kościół. Budzenie świadomości o małżeństwie i życiu w rodzinie jest bardzo istotne, chociażby z tego powodu, iż większość ludzi swoje powołanie odczytuje właśnie w małżeństwie. Pomocą w odkrywaniu naturalnego charakteru małżeństwa i jego miejsca w zbawczym planie, służy wrodzona zdolność człowieka do małżeństwa ${ }^{36}$.

Kolejny pasterz - papież Franciszek, często wypowiada się w materii przygotowania do zawarcia sakramentalnego małżeństwa ${ }^{37}$. I tak, w adhortacji Amoris laetitia wskazał na cel przygotowania do

35 Kan. 1058 w: Codex Iuris Canonici auctoritate Ioannis Pauli PP. II promulgatus, 25.01.1983, AAS 75 (1983), cz. II, s. 1-317; Jan Paweł II, Kodeks Prawa Kanonicznego przekład polski zatwierdzony przez Konferencję Episkopatu, Poznań 1984 (dalej: $\mathrm{KPK})$.

36 Benedy k XVI, Ad sodales Tribunalis Romanae Rotae, dz. cyt.

37 Warto wskazać m.in. na treść katechez wygłaszanych podczas audiencji środowych: Nauczanie papieża Franciszka: audiencje i katechezy, 29 kwietnia - 27 maja 2015 r., https://opoka.org.pl/nauczanie/nauczanie-papieza-franciszka-audiencje-i-katechezy (dostęp 30.12.2019); zwołanie XIV Zgromadzenia Zwyczajnego Synodu Biskupów w 2015 r.: Powołanie i misja rodziny w Kościele i świecie współczesnym. Dokumenty i komentarz. XIV Zgromadzenie Zwyczajne Synodu Biskupów, Kraków 2016; ogłoszenie adhortacji apostolskiej Amoris laetitia: FrancIszek, Posynodalna Adhortacja apostolska Amoris laetitia, 19.03.2016, Kraków 2016. (dalej: AL); czy wygłoszenie alokucji do członków Trybunału Roty Rzymskiej 21 stycznia 2017: Franciszer, Potrzebny jest „nowy katechumenat” w przygotowaniu do małżeństwa, https://opoka.org.pl/biblioteka/W/WP/franciszek_i/przemowienia/rota_21012017. html (dostęp 30.12.2019). 
małżeństwa - chodzi o odkrycie przez młodych ludzi wartości i bogactwa małżeństwa ${ }^{38}$. Narzeczeni mają mieć przede wszystkim „możliwość poznania atrakcyjności pełnej jedności”. Jedność „uwzniośla i udoskonala społeczny wymiar życia, przyznaje jej najwspanialszy sens, promuje dobro dzieci i daje im najlepsze warunki dla ich dojrzewania i wychowania" ${ }^{39}$. Należy zauważyć, że papież Franciszek sprawę jedności w małżeństwie, a zatem relacji międzyosobowej, traktuje priorytetowo, dobro zaś dzieci ukazuje w bezpośrednim, głębokim związku jedności miłości małżeńskiej, co ma wpływ na jakość i wartość życia całego społeczeństwa. Do koniecznej formacji narzeczonych, angażującej całą społeczność chrześcijańską, należy katecheza o znaczeniu cnót, zwłaszcza cnoty czystości, która jest „cennym warunkiem autentycznego rozwoju prawdziwej miłości międzyosobowej" ${ }^{\prime 0}$. W tym dokumencie Franciszek nie używa terminu „katechumenat”, ale wskazuje na zakorzenienie przygotowania do małżeństwa w procesie inicjacji chrześcijańskiej, z zaakcentowaniem powiązania małżeństwa $\mathrm{z}$ chrztem oraz $\mathrm{z}$ innymi sakramentami ${ }^{41}$. Papież podkreśla, że przygotowanie ma być odnowionym przepowiadaniem kerygmatu $z$ priorytetowym potraktowaniem tych treści, które przekazywane w sposób atrakcyjny i przyjazny pomogą narzeczonym zaangażować się z wielkodusznością i wolnością w proces trwający całe życie. Ojciec Święty stwierdza, że jest to „rodzaj inicjacji do sakramentu małżeństwa”. Takie przygotowanie powinno zapewnić narzeczonym najlepszą dyspozycję do przyjęcia sakramentu i rozpoczęcia przez nich solidnego życia rodzinnego ${ }^{42}$. Franciszek ten etap przygotowania określa jako „dojrzewanie miłości narzeczonych poprzez towarzyszenie wypełnione bliskością i świadectwem"43.

\footnotetext{
38 AL, 205-216.

39 TAMŻE.

40 AL, 206.

41 TAMŻE.

42 AL, 207.

43 AL, 208.
} 
Idąc za wskazaniem kodeksowym, to poszczególne konferencje episkopatów są odpowiedzialne za kształt formacji przygotowującej do zawarcia sakramentu małżeństwa ${ }^{44}$. Interesujący etap przygotowania bliższego na terenie Polski znajduje swoje odzwierciedlenie w następujących dokumentach: II Polski Synod Plenarny (1991-1999) ${ }^{45}$, Dyrektorium Duszpasterstwa Rodzin ${ }^{46}$ oraz Stużyć prawdzie o matżenstwie i rodzinie ${ }^{47}$.

Wielkim wydarzeniem dla Kościoła w Polsce był II Polski Synod Plenarny. W jego przebieg zaangażowała się wielka rzesza społeczeństwa polskiego. Przedmiotem obrad była m.in. problematyka powołania do życia w małżeństwie i rodzinie. Synod zwrócił uwagę na to, że przygotowanie do odpowiedzialnej realizacji powołania małżeńskiego winno wiązać się z całościową formacją ludzką. „Jakim jest ktoś człowiekiem, jakim jest chrześcijaninem, takim będzie współmałżonkiem i rodzicem" ${ }^{\text {". }}$. Kształtowanie tak zarysowanej postawy dokonuje się w domu rodzinnym w oparciu o jej potrójną misję: prorocką, kapłańską i królewską. Pierwsza z tych misji dokonuje się poprzez to, że rodzina to wspólnota ewangelizowana i ewangelizująca, druga misja dokonuje się w „sanktuarium domowym”, w którym każdy ma ważną rolę w praktykowaniu kapłaństwa chrzcielnego i otwartości na inne sakramenty. Trzecia misja rodziny uczy ducha służby sobie nawzajem oraz wychodzenia w postawie służebnej na zewnątrz. Jest to realizacja przykazania miłości wobec najbliższych, a potem wobec innych ${ }^{49}$.

Dyrektorium Duszpasterstwa Rodzin to dokument, który wszedł w życie 1 maja 2003 r. Uwzględnia on zadania osób duchownych oraz laikatu, zwłaszcza rodzin, zaangażowanych w tworzenie właściwych

\footnotetext{
44 Kan. 1067 KPK.

45 II Polski Synod Plenarny (1991-1999), Powołanie do życia w małżeństwie i rodzinie, Poznań 2001 (dalej: PSP).

46 Por. przypis nr 5.

47 Konferencja Episkopatu Polski, Służyć prawdzie o małżeństwie i rodzinie (19.06.2009), Warszawa 2009 (dalej: SPoMR).

48 PSP, 41.

49 PSP, 33.
} 
warunków dla małżeństw i rodzin ${ }^{50}$. Przygotowanie bliższe do małżeństwa jest kontynuacją formacji dokonującej się na poziomie szkół średnich. Katecheza na tym etapie przybiera formę katechumenatu odkrywającego na nowo wartość i znaczenie sakramentu małżeństwa. Chodzi o to, by ten sakrament był sprawowany i przeżywany w należytym usposobieniu moralnym i duchowym. Przygotowanie to ma ukazywać małżeństwo jako relację międzyosobową mężczyzny i kobiety, wymagającą stałego rozwoju, pobudzającą do pogłębienia problemów płciowości małżeńskiej i odpowiedzialnego rodzicielstwa. W konsekwencji do poszerzania horyzontów dotyczących metod wychowania dzieci, a w dalszej perspektywie do zaangażowania się $\mathrm{w}$ apostolat rodzin ${ }^{51}$. Tak więc omawiany etap ma swoim zasięgiem poruszyć trzy wymiary: intelektualny - pogłębić chrześcijańską naukę o małżeństwie i rodzinie; społeczny - przysposobić do życia w rodzinie na równych prawach w poczuciu odpowiedzialności i współpracy; religijny - wprowadzić w głębsze życie wspólnotowo-religijne ${ }^{52}$. Katecheza dla jej jak największej owocności powinna zawierać elementy: wspólnotowo-liturgiczny, konferencyjny oraz dialogowy. Autorzy dokumentu przewidują realizację tego przedsięwzięcia zasadniczo w ramach parafii - jako program optymalny - należy w ciągu roku przeprowadzić przynajmniej 25 katechez, przy współudziale Zespołu Pastoralnego (w jego skład wchodzić mają duszpasterze, świeccy liderzy grup parafialnych, doradcy życia rodzinnego). Zespół ten ma dokonać adaptacji programu katechizacji przedmałżeńskiej do miejscowych warunków i ma czuwać nad jego wykonaniem ${ }^{53}$. Pojawia się w dokumencie również wariant minimalistyczny, możliwy do zastosowania jedynie w ostateczności dla osób, które mają przeszkody do wzięcia udziału we wcześniej wymienionych kursach. Chodzi o blok 10 spotkań formacyjnych ${ }^{54}$.

\footnotetext{
50 DDR, 1.

51 DDR, 25.

52 DDR, 24.

53 DDR, 25.

54 DDR, 26.
} 
Zadaniem działań w ramach przygotowania obok pogłębienia nauki o małżeństwie i rodzinie jest uwrażliwienie słuchaczy na fałszywe teorie w obszarze dotyczącym małżeństwa i rodziny ${ }^{55}$.

Trzeci z wymienionych dokumentów Episkopatu Polski zatytułowany Służyć prawdzie o małżeństwie i rodzinie nie jest teoretycznym opracowaniem zagadnień małżeńsko-rodzinnych, ale duszpasterską refleksją w tej materii. Sami biskupi piszą: „z duszpasterską troską mówimy tutaj o tym, co uważamy za najważniejsze i pożyteczne na tym etapie dziejów Kościoła w Polsce" ${ }^{56}$. Czas przygotowania do sakramentu małżeństwa nazwano w dokumencie czasem intensywnej ewangelizacji. Biskupi tym samym chcą z mocą podkreślić doniosłość tego etapu w ogromnej mierze wpływającego na kształt życia małżeńskiego i rodzinnego. Zarówno duszpasterze, jak i sami narzeczeni „muszą na nowo odkryć jego ważność. (...) Trzeba, aby był to czas intensywnej ewangelizacji, prowadzącej do nawrócenia, czyli w tym wypadku - odkrycia bądź pogłębienia Bożej wizji małżeństwa oraz odkrycia, bądź ożywienia osobistej zażyłości z Bogiem"57. Apel biskupów o wzmożenie działań zmierzających w kierunku pogłębienia relacji: kandydat do małżeństwa a Bóg, jest bardzo dynamiczny, wskazujący jednocześnie na jego wagę.

\section{Wnioski}

Zestawiając aktualnie obowiązujące unormowania dotyczące dwóch pierwszych etapów przygotowania do małżeństwa, warto zwrócić uwagę na kształtującą się wizję Kościoła w przedmiotowej materii. Odpowiedzialne organy władzy Kościoła powszechnego zasadniczo kładą akcent na przygotowanie bliższe. Tym samym pozostawiają one większe pole kreatywności organom władzy niższego szczebla w zaprojektowaniu i realizacji przygotowania dalszego do małżeństwa. W odpowiedzi na taką konstrukcję, Episkopat Polski

\footnotetext{
55 DDR, 24.

56 SPoMR, 4.

57 SPoMR, 98.
} 
więcej uwagi poświęcił w wydanych przez siebie dokumentach trosce rodziny o kształtowanie postaw promałżeńskich i prorodzinnych u swoich dzieci. Zwraca się szczególną uwagę na postawę świadectwa ze strony rodziców i opiekunów. Świadectwo to dotyczy zwłaszcza relacji między nimi. Pojawia się tu cała paleta rozmaitych odniesień, zachowań, reakcji wewnątrzrodzinnych, postaw kształtujących nie tylko szacunek, ale ofiarną miłość.

W przygotowaniu bliższym dokumenty KEP w przeważającej mierze koncentrują uwagę na kursach przedmałżeńskich, na ich treści i formach. W zamyśle pasterzy Kościoła w Polsce etap ten jest realizowany zasadniczo na poziomie ostatnich klas szkoły ponadgimnazjalnej - obecnie, ponadpodstawowej. Oznacza to, że odbywa się on wówczas, kiedy kursanci są w wieku osiemnastego/dziewiętnastego roku życia. Problem w tym, że aktualnie mężczyźni zawierają małżeństwa w wieku średnio trzydziestu lat, zaś kobiety średnio w wieku dwudziestu ośmiu lat ${ }^{58}$. Odstęp czasowy pomiędzy przygotowaniem bliższym a czasem zawierania małżeństwa jest stosunkowo duży, wynosi bowiem ok. dziesięciu lat, dlatego stanowi wyzwanie dla odpowiedzialnych za strukturalne przygotowanie do małżeństwa. Kierunek rozwiązywania problemu nadają dokumenty Kościoła powszechnego. Zarówno Papieska Rada ds. Rodziny w zaprezentowanym dokumencie, jak również po nim wydane regulacje, koncentrują uwagę na narzeczonych. Cała formacja bliższego przygotowania oraz wszelkie sugestie skierowane są ku narzeczonym, czyli tym którzy są już zdecydowani na małżeństwo z konkretną przez siebie wybraną osobą. Wspólne wzięcie udziału narzeczonych w przygotowaniu bliższym może być dobrym pretekstem do podejmowania wspólnych dyskusji na tematy poruszane w ramach kursu, a dotyczące ich wspólnej przyszłości realizowanej w świetle nauki Kościoła. Niewątpliwie, najlepszym miejscem odbywania kursu przedmałżeńskiego byłaby praktycznie parafia zamieszkania/pobytu narzeczonych lub inne miejsce,

58 Dane przytoczone dotyczą roku 2018, opublikowane w 2019, w: https://www. bankier.pl/wiadomosc/9-wykresow-o-slubach-i-rozwodach-Polakow-7716897.html (dostęp 19.01.2021). 
w którym Kościół przeprowadzałby cykl zajęć przewidzianych dla narzeczonych. Umiejętne połączenie wykładów, dyskusji i ćwiczeń z dniami skupienia czy nawet rekolekcjami dla narzeczonych byłoby wielopłaszczyznowym dobrodziejstwem, które zaowocowałoby w ich wspólnocie małżeńskiej.

\section{Preparation for further and closer marriage following the general decree of the Polish Bishops' Conference of 2019 \\ Summary}

Getting married in the Catholic Church should be preceded by preparation divided into three stages: further, closer and direct. In Poland, since June $1^{\text {st }}, 2021$, an episcopal document is in force, specifying in particular canonical and pastoral talks with the engaged couples. The earlier stages of marriage formation have been discussed in scattered legal acts. These documents have the scope of the universal Church and the others are in force in Poland. This study summarizes the regulations that are in force in Poland, regarding further and closer marriage preparation. Some changes were suggested, for the welfare of marriage.

Słowa kluczowe: przygotowanie dalsze, przygotowanie bliższe, narzeczeni, Kościół w Polsce

Keywords: further preparation, closer preparation, the spouses, Church in Poland

\section{Nota o autorze}

Ks. Kazimierz Dullak - profesor Uniwersytetu Szczecińskiego, kapłan diecezji koszalińsko-kołobrzeskiej, prodziekan ds. studenckich Wydziału Teologicznego US. 